\title{
Oxygen Reduction Behavior of Rutile-type Iridium Oxide in Sulfuric Acid Solution
}

\begin{abstract}
Norihiro Yoshinaga, Wataru Sugimoto and Yoshio Takasu*
Department of Fine Materials Engineering, Faculty of Textile Science and Technology, Shinshu University, 3-15-1 Tokida, Ueda, 386-8567, Japan
\end{abstract}

\section{Abstract}

Two different forms of rutile-type iridium oxide catalysts were prepared: $\mathrm{IrO}_{2}$-coated titanium plate electrocatalysts prepared by a dip-coating method $\left(\mathrm{IrO}_{2} / \mathrm{Ti}\right)$ and iridium oxide nanoparticles $\left(\mathrm{IrO}_{2}\right)$ prepared by a wet method, the Adams fusion method. The catalytic behavior of the oxygen reduction reaction (ORR) was evaluated by cyclic voltammetry in $0.5 \mathrm{M} \mathrm{H}_{2} \mathrm{SO}_{4}$ at $60^{\circ} \mathrm{C}$. Both catalysts were found to exhibit considerable activity for the ORR; however, the former oxide electrodes showed higher activity than the latter ones. All the $\mathrm{IrO}_{2} / \mathrm{Ti}$ catalyst electrodes heat-treated at a temperature between $400^{\circ} \mathrm{C}$ and $550^{\circ} \mathrm{C}$ showed ca. $0.84 \mathrm{~V}$ (vs RHE) of the onset potential for the ORR, $E_{\mathrm{ORR}}$, where the reduction current of oxygen had begun to be observed during the cathodic potential sweep of the test electrodes. It has been confirmed clearly that $\mathrm{IrO}_{2}$, but neither metallic Ir nor the hydrated $\mathrm{IrO}_{2}$, behaves as an active catalyst for the ORR in an acidic solution. It was also demonstrated that the enlargement of the surface area of the $\mathrm{IrO}_{2} / \mathrm{Ti}$ with the help of lanthunum is effective for the enhancement of the catalytic activity in the reaction.

Keywords: Iridium oxide, Oxygen reduction reaction, Electrocatalyst, Fuel cell, Oxide cathode 
* Corresponding author.

E-mail address: ytakasu@shinshu-u.ac.jp (Y. Takasu)

\section{Introduction}

Fuel cells have attracted the public's attention from both an environmental and a convenience perspective but the technology has not yet become beneficial to the public in terms of availability, cost, durability, size, and so forth.

Although the typical cathode catalyst used for Polymer Electrolyte Fuel Cells (PEFCs) is $\mathrm{PtCo} / \mathrm{C}$, due to its high oxygen reduction activity[1-4], further enhancement of both catalytic activity and durability is needed before its use becomes practical. The overpotential for the oxygen reduction reaction (ORR) needs to be reduced, and the dissolution of the metal elements has to be minimized [5]. Various approaches have been conducted to overcome these problems, including alloying Pt with other metals and searching for other suitable compounds, including oxides [6-8], carbides [9,10], nitrides, silicides, metal complexes [11,12], and other compounds [13-16]. Recently, some interesting studies on the development of Pt-free oxide cathodes, such as $\mathrm{TaO}_{0.92} \mathrm{~N}_{1.05}$ and $\mathrm{ZrO}_{2-x}$, have been reported [17,18]. Although these and numerous other studies have significantly contributed to the development of PEFC and DMFC, further investigation is still required for the improvement of both activity and durability. Iridium oxide is a typical material that resists corrosion in acidic solutions. Since $\mathrm{IrO}_{2}$ is one of the outstanding electrocatalysts for oxygen evolution, $\mathrm{IrO}_{2}-\mathrm{Ta}_{2} \mathrm{O}_{5} / \mathrm{Ti}$ electrodes $[19,20]$ have been used as oxygen-evolving anodes in the industrial electro-plating process. The $\mathrm{IrO}_{2}-\mathrm{RuO}_{2}-\mathrm{TiO}_{2} / \mathrm{Ti}$ ternary oxide electrode is widely used as the Dimensionally Stable Anode (DSA ${ }^{\circledR}$ ) catalyst-electrode in the electrolysis process for chlorine production in chlor-alkali industries [21]. Although basic investigations on the ORRs of iridium metal [22,23], iridium alloy electrodes [24,25], unhydrated or hydrated iridium oxide as support of platinum particles [26,27] as well as the ORR of iridium oxide in an alkaline solution [28,29] have been published. Studies on crystalline iridium oxide in acidic solutions has scarcely been reported on to date [30,31]. In previous investigations [30,31], these authors reported results concerning the ORR activity of a dip-coated $\mathrm{IrO}_{2} / \mathrm{Ti}$ electrocatalyst.

This study presents fundamental results on the iridium oxide catalysts 
for ORR, using both iridium oxide coated on a Ti plate substrate prepared by a dip-coating method $\left(\mathrm{IrO}_{2} / \mathrm{Ti}\right)$ and $\mathrm{IrO}_{2}$ nanoparticles prepared by a wet method, the Adams fusion method. Besides the fundamental information on the electrocatalytic property of $\mathrm{IrO}_{2}$, the results must provide ideas to design less-expensive oxide cathode catalysts for the ORR.

\section{Experimental}

\subsection{Preparation of $\mathrm{IrO}_{2} /$ Ti electrodes by a dip-coating method}

Rutile-type $\mathrm{IrO}_{2}$ coating-film was prepared on a Ti plate $(10 \times 10 \times 1 \mathrm{~mm})$ substrate by a conventional dip-coating method using a butanolic solution of iridium chloride $\left(\left[\mathrm{IrCl}_{3}\right]=0.5 \mathrm{M}\right)$. The titanium substrates were etched with $10 \%$ oxalic acid at $80^{\circ} \mathrm{C}$ for $1 \mathrm{~h}$, and then rinsed with deionized water before the dipping procedure. Calcination of the dip-coated salts was conducted at various air temperatures between $400^{\circ} \mathrm{C}$ and $550^{\circ} \mathrm{C}$. The dip-drying/calcination (aternating $10 \mathrm{~min}$ each) procedure was repeated 7 times. An $\mathrm{IrO}_{2} / \mathrm{Ti}$ electrode with extremely enlarged surface area was prepared using a dip-coating solution containing $\mathrm{IrCl}_{3}$ and $\mathrm{LaCl}_{3}$ in butanol $\left(\left[\mathrm{IrCl}_{3}\right]=\left[\mathrm{LaCl}_{3}\right]=0.5 \mathrm{M}\right)[32,33]$. After the dip-drying/calcination $\left(450^{\circ} \mathrm{C}, 10 \mathrm{~min}\right)$ procedure was repeated 7 times, any of the lanthanum species were completely removed with $0.5 \mathrm{M} \mathrm{H}_{2} \mathrm{SO}_{4}$ at $60^{\circ} \mathrm{C}$. No traces of lanthumun species were detected after the acid treatment. This electrode was denoted to be $\mathrm{La}_{2} \mathrm{O}_{3}$-treated $\mathrm{IrO}_{2} / \mathrm{Ti}$ electrode in this study.

\subsection{Preparation of $\mathrm{IrO}_{2}$ nanoparticles by the Adamds fusion method}

Iridium oxide powder, $\mathrm{IrO}_{2}$, was prepared by the Adams fusion method [32]. A metal precursor $\left(\mathrm{H}_{2} \mathrm{IrCl}_{6} \cdot n \mathrm{H}_{2} \mathrm{O}\right)$ was added to $10 \mathrm{~mL}$ of 2-propanol to achieve a total metal concentration of $0.07 \mathrm{~mol} \mathrm{~L}^{-1}$. This was magnetically stirred for $2 \mathrm{~h}$ to ensure complete dissolution of the precursor; this was followed by the addition of $10 \mathrm{~g}$ of finely ground $\mathrm{NaNO}_{3}$. This solution- $\mathrm{NaNO}_{3}$ mixture was heated at an air temperature of $70^{\circ} \mathrm{C}$ until completely dry. The dry salt mixture was then placed into a preheated furnace between $400^{\circ} \mathrm{C}$ and $500^{\circ} \mathrm{C}$ for $30 \mathrm{~min}$. The fused salt-oxide mixture was cooled down slowly to room temperature, then washed three times in deionized water to remove the remaining salts. The iridium oxide was separated by centrifugation and the recovered oxide powder dried in air at $70^{\circ} \mathrm{C}$.

\subsection{Electrochemical measurements}

The ORR activity of these oxide electrodes was evaluated by cyclic voltammetry $(\mathrm{CV})$ in $0.5 \mathrm{M} \mathrm{H}_{2} \mathrm{SO}_{4}$ using a beaker-type electrolytic cell, in a stationary state at $60^{\circ} \mathrm{C}$. The test electrode of the $\mathrm{IrO}_{2}$ nanoparticles was prepared using the thin-film electrode method $[33,34]$. Briefly, $10 \mu \mathrm{g}$ of the 
oxide powder was dispersed in $10 \mathrm{~mL}$ of water and was subjected to ultrasonification for $30 \mathrm{~min}$. Then, $40 \mu \mathrm{L}$ of the oxide powder dispersion was dropped onto a mirror-polished Glassy Carbon (GC) of the rotating disk electrode $\left(0.196 \mathrm{~cm}^{2}\right.$ exposed surface). After drying at $60^{\circ} \mathrm{C}, 20 \mu \mathrm{L}$ of a $0.03 \mathrm{wt} \%$ Nafion $^{\circledR}$ alcoholic dispersion was also dropped onto the electrode surface to stabilize the oxide particles on the GC surface.

A carbon felt, rather than $\mathrm{Pt}$, was used as the counter electrode in order to avoid the deposition of $\mathrm{Pt}$ onto the test electrode through dissolution. Although an $\mathrm{Ag} / \mathrm{AgCl}$ reference electrode was used, the electrode potential is presented vs RHE. A Luggin capillary faced the working electrode at a distance of $2 \mathrm{~mm}$. All electrode potentials are referred to the RHE $(t)$ scale, corrected for temperature effect. For the ORR experiment, oxygen gas was bubbled into the $0.5 \mathrm{M} \mathrm{H}_{2} \mathrm{SO}_{4}$ solution at $60^{\circ} \mathrm{C}$.

\section{Results and discussion}

3.1. Surface morphology and structure of $\mathrm{IrO}_{2} / \mathrm{Ti}$ electrodes prepared at various temperatures

The $\mathrm{IrO}_{2} / \mathrm{Ti}$ electrodes prepared by this dip-coating method show typical surface morphology and crystal structure, as reported in many studies so far [35-39]. The typical scanning electron micrograph (SEM) of an $\mathrm{IrO}_{2} / \mathrm{Ti}$ electrode prepared at $450^{\circ} \mathrm{C}$ is shown in Figs. 1(A) and 1(B). The white particles seen in the SEM image are $\mathrm{IrO}_{2}$ crystallites (Fig. 1(B)-a)), and the flat part is also composed of fine $\mathrm{IrO}_{2}$ particles that are connected to each other to form a porous structure (Fig. 1(B)-b)). The $\mathrm{X}$-ray diffraction (XRD) patterns of the $\mathrm{IrO}_{2} / \mathrm{Ti}$ electrodes prepared at various temperatures between $400^{\circ} \mathrm{C}$ and $550^{\circ} \mathrm{C}$ are shown in Fig. 2. These patterns show that rutile-type $\mathrm{IrO}_{2}$ was formed on the Ti substrate under the preparation temperatures. Both the intensity and half-width of these diffraction peaks, especially the (110) diffraction peak at $2 \theta=27.7^{\circ}$, show that the crystallinity of $\mathrm{IrO}_{2}$ increases with heat-treatment temperature.

\subsection{ORR behavior of $\mathrm{IrO}_{2} /$ Ti electrodes}

Figure 3 shows $\mathrm{CVs}$ of the $\mathrm{IrO}_{2} / \mathrm{Ti}$ electrodes heat-treated at various temperatures for $10 \mathrm{~min}$, between $400^{\circ} \mathrm{C}$ and $550^{\circ} \mathrm{C}$, in $\mathrm{N}_{2}$-saturated $0.5 \mathrm{M}$ $\mathrm{H}_{2} \mathrm{SO}_{4}$ (dotted lines, a)) and in $\mathrm{O}_{2}$-saturated $0.5 \mathrm{M} \mathrm{H}_{2} \mathrm{SO}_{4}$ (solid lines, b)). During both potential scans (anodic and cathodic potential sweeps), an additional cathodic current was observed for those CVs measured with an $\mathrm{O}_{2}$-saturated solution, as compared with those measured with an $\mathrm{N}_{2}$-saturated solution. This additional cathodic current is due to the ORR on each of the oxide electrodes. Figure 4 shows the ORR cathodic current curves presented in each geometric surface area, for the electrodes, which were obtained by subtracting the voltammogram of the $\mathrm{O}_{2}$-saturated 
solution during a cathodic scan from that of the $\mathrm{N}_{2}$-saturated electrolytes. With an increase in heat-treatment temperature, the cathodic current for the ORR decreases. In order to clarify the effect of the heat-treatment temperature of $\mathrm{IrO}_{2} / \mathrm{Ti}$ on the current density, the current densities per effective surface area of these electrodes must be compared, where the effective surface area does not mean the real surface area determined by the BET (Burnauer-Emmett-Teller) method but the surface area which contributes to the ORR reaction under static condition without rotating of the test electrode in the electrolyte. Although it is not easy to determine the effective surface area of these electrodes in the ORR reaction, the current densities for the ORR on these electrodes can be estimated by the division of the current shown in Fig. 4 with the pseudo-capacitance of these $\mathrm{IrO}_{2} / \mathrm{Ti}$ electrodes. The estimated surface area, ESA, of these electrodes was evaluated using the cyclic voltammograms measured on the $\mathrm{N}_{2}$-saturated electrolytes shown in Fig. 3, assuming that of the monolayer capacitance of the $\mathrm{IrO}_{2}$ was $80 \mu \mathrm{F} \mathrm{cm}{ }^{-2}$, the same as that of $\mathrm{RuO}_{2}[40,41]$. The $j-E$ curves of these electrodes are shown in Fig. 5. Since the voltammetry was carried out under a stationary state, the ORR current densities of these electrodes must be compared carefully; however, the $j-E$ curve characteristics of these electrodes with a current density $(j)$ lower than ca. $0.5 \mu \mathrm{A} \mathrm{cm}^{-2}$ are almost the same. This strongly suggests that the quality of the active sites of these $\mathrm{IrO}_{2} / \mathrm{Ti}$ electrodes for the ORR was the same, even if heat-treatment temperature was different under these conditions. The $E_{\text {ORR }}$ values, which means the electrode potential where the redcuction current of oxygen that began to be observed during the cathodic potential sweep of the test oxide electrodes of these electrodes may also be the same, ca. $0.84 \mathrm{~V}$ (vs RHE). The $\mathrm{IrO}_{2}$ layers of these $\mathrm{IrO}_{2} / \mathrm{Ti}$ electrodes were not hydrated oxide but anhydrous oxide, because the XRD peak intensity of these electrodes were strong (Fig. 2) and the profiles of the cyclic voltammograms of them in $\mathrm{N}_{2}$-saturated solution (Fig. 5) were almost same in spite of the decrease in the pseudo-capacitance with the preparation temperature. However, a more precise examination of the current density and the $E_{\mathrm{ORR}}$ is needed to understand the effect of heat-treatment temperature on the quality of the active sites on the $\mathrm{IrO}_{2} / \mathrm{Ti}$ catalyst electrode. In particular, the potential effect of titanium ions diffused from the oxide/titanium interface to the $\mathrm{IrO}_{2}$ oxide layer, when the electrode is heat-treated at high temperature, must be checked. In spite of the potential effect of titanium ions from the oxide/titanium interface, DSA-type electrodes have many advantages: the coating layer is composed of fine oxide particles connected to each other to form a micro/meso porous structure, the titanium substrate is protected from corrosion by the formation of a dense oxide layer at the interface between the porous oxide coating and titanium substrate, and preparation 
of the electrodes is easy and useful for the search of new electrocatalysts.

\subsection{Enhancement of the ORR activity of $\mathrm{IrO}_{2} /$ Ti electrode}

In order to find any methods to enhance the ORR activity of less-expensive oxides, the authors have examined the enhancement of the catalytic activity of $\mathrm{IrO}_{2} / \mathrm{Ti}$ electrode for the ORR using two different methods. The first method is the formation of a solid solution to change the valency of iridium ions with another element, vanadium for example [31], and the second one is the use of rare earth elements to enlarge the surface area of oxides [33,34]. When a DSA-type binary oxide electrode was prepared with a dip-coating solution containing iridium salt and a rare earth salt, the resulting electrode was composed of a composite oxide of each element so long as the calcination temperature was not too high. Since the rare earth oxide can easily be removed by acid, a porous $\mathrm{IrO}_{2}$ layer with extremely enlarged surface area remained after the acid treatment of the composite electrode.

A typical SEM image of a $\mathrm{La}_{2} \mathrm{O}_{3}$-treated $\mathrm{IrO}_{2} / \mathrm{Ti}$ electrode presented in Fig. 6 shows no existence of large crystallites besides many meso pores. An elemental X-ray analysis showed no trace of lanthanum remained in the oxide coating after the acid treatment. A steady state cyclic voltammogram of this electrode is given in Fig. 7 with that of the $\mathrm{IrO}_{2} / \mathrm{Ti}$ electrode prepared at $450^{\circ} \mathrm{C}$ already presented in Fig. 3-b) for comparison. The pseudo-capacitance of the former electrode, a), is about 8.5 times as large as that of the latter one, b). Therefore, an $\mathrm{IrO}_{2} / \mathrm{Ti}$ electrode with highly enlarged surface area was prepared by the dip-coating method with the help of lanthanum during the preparation procedure of the electrode. Figure 8 shows the ORR behavior of three different oxide electrodes prepared at $450^{\circ} \mathrm{C}$; the $\mathrm{IrO}_{2} / \mathrm{Ti}$ electrode, the $\mathrm{La}_{2} \mathrm{O}_{3}$-treated $\mathrm{IrO}_{2} / \mathrm{Ti}$ electrode, and the porous $\operatorname{Ir}_{0.6} \mathrm{~V}_{0.4} \mathrm{O}_{2} / \mathrm{Ti}$ electrode, which was reported in the previous paper [31]. The ORR characteristics of a platinum plate electrode are also presented in Fig. 8 for comparison. The $\mathrm{La}_{2} \mathrm{O}_{3}$-treated $\mathrm{IrO}_{2} / \mathrm{Ti}$ electrode, b), showed higher current density for the ORR than that of the $\mathrm{IrO}_{2} / \mathrm{Ti}$ electrode, a), and its onset potential for the ORR, $E_{\text {ORR }}$, was ca. $0.88 \mathrm{~V}$ vs RHE which is somewhat higher than the value of the $\mathrm{IrO}_{2} / \mathrm{Ti}$ electrode, $0.84 \mathrm{~V}$ vs RHE. As has been discussed in the previous paper [31], the porous $\operatorname{Ir}_{0.6} \mathrm{~V}_{0.4} \mathrm{O}_{2} / \mathrm{Ti}$ electrode showed the onset potentials for the ORR to be $E_{\text {ORR }}=0.90 \mathrm{~V}$ and $E_{\text {ORR-20 }}=0.86 \mathrm{~V}$ vs RHE, where $E_{\text {ORR-20 }}$ means the electrode potential where the oxygen reduction current attained $20 \mu \mathrm{A}$ $\mathrm{cm}^{-2}$-(geometric) [31] and exhibited twice the activity of a flat Pt plate electrode at $0.8 \mathrm{~V}$ (vs RHE), when the current density for the ORR was evaluated with the geometric surface area. This oxide electrode may have a roughness factor of several decades; therefore, the actual effective surface 
area of this porous oxide electrocatalyst requires evaluation. Although the ORR activity of both oxide electrodes of the $\mathrm{La}_{2} \mathrm{O}_{3}$-treated $\mathrm{IrO}_{2} / \mathrm{Ti}$ and the $\mathrm{Ir}_{0.6} \mathrm{~V}_{0.4} \mathrm{O}_{2} / \mathrm{Ti}$ were still lower than the platinum electrode, the enlargement of the surface area of the $\mathrm{IrO}_{2} / \mathrm{Ti}$ oxide electrode with the help of lanthunum and the formation of the solid solution with appropriate other elements, vanadiun in this case, can considerably enhance the catalytic activity of the $\mathrm{IrO}_{2} / \mathrm{Ti}$ oxide electrode. When the current density for the ORR of each geometric surface area of the $\mathrm{La}_{2} \mathrm{O}_{3}$-treated $\mathrm{IrO}_{2} / \mathrm{Ti}$ electrode shown in Fig. 7 was divided by the pseudo-capacitance, the voltammogram presented by the $j_{(\mathrm{ESA})}-E$ curve did not rest on the group of the voltammograms shown in Fig. 5, but the voltammogam rested on about half of the $j_{\text {(ESA) }}$ for the $\mathrm{IrO}_{2} / \mathrm{Ti}$ electrode prepared at $450^{\circ} \mathrm{C}$ in the region lower than ca. $1.0 \mu \mathrm{A} \mathrm{cm}^{-2}$. This deviation must be caused either by the extremely enhanced surface area or by the possibly characteristic pore strucure of the $\mathrm{IrO}_{2}$ formed by the dissolution of lanthunum oxide from the Ir-La composite oxide layer. These methods provide useful information on the design of the oxide cathode catalysts using less-expensive elements.

\subsection{Characteristics of $\mathrm{IrO}_{2}$ nanoparticles synthesized using the Adams fusion method}

In order to evaluate the ORR characteristics of $\mathrm{IrO}_{2}$ without the potential effect of titanium ions on the catalytic behavior of $\mathrm{IrO}_{2} / \mathrm{Ti}$ electrocatalysts, iridium oxide powder was synthesized using the Adams fusion method. In Fig. 9, the XRD patterns of the $\mathrm{IrO}_{2}$ powder heat-treated at $400^{\circ} \mathrm{C}, 450^{\circ} \mathrm{C}$, or $500^{\circ} \mathrm{C}$ for $30 \mathrm{~min}$ in air are presented. The intensity of the rutile-type XRD peaks increased with an increase in heat-treatment temperature; however, that of the (101) at $2 \theta=\mathrm{ca} .34 .6^{\circ}$ increased slightly, and its half-width decreased considerably with temperature, showing an increase in crystallite size. Figures 10(A), 10(B) and 10(C) show the transmission electron micrographs (TEM) of these $\mathrm{IrO}_{2}$ powders. The increase in crystallite size along with heat-treatment temperature, is clearly demonstrated in these photographs. Lattice stripes are observed on the $\mathrm{IrO}_{2}$ crystallites heat-treated at every temperature.

\subsection{ORR behavior of $\mathrm{IrO}_{2}$ nanoparticles}

Figures $11(\mathrm{~A})-11(\mathrm{C})$ show cyclic voltammograms of the $\mathrm{IrO}_{2}$ particles in $\mathrm{N}_{2}$-saturated $0.5 \mathrm{M} \mathrm{H}_{2} \mathrm{SO}_{4}$ (broken lines) and in $\mathrm{O}_{2}$-saturated $0.5 \mathrm{M}$ $\mathrm{H}_{2} \mathrm{SO}_{4}$ (solid lines) measured in a stationary state and rotated at $2000 \mathrm{rpm}$ (long- and short-dashed lines). As in the case of the $\mathrm{IrO}_{2} / \mathrm{Ti}$ electrodes, an additional cathodic current due to the ORR was observed on each of the oxide electrodes. The apparent onset electrode potentials for the ORR $\left(E_{\mathrm{ORR}}\right)$ on $\mathrm{IrO}_{2}$ heat-treated at $400^{\circ} \mathrm{C}, 450^{\circ} \mathrm{C}$ and $500^{\circ} \mathrm{C}$ were ca. $0.60 \mathrm{~V}$ (vs 
RHE), ca. $0.69 \mathrm{~V}$ (vs RHE), and ca. $0.62 \mathrm{~V}$ (vs RHE), respectively. As for the reason why the onset potential for the ORR of these $\mathrm{IrO}_{2}$ electrodes was lower than that for the $\mathrm{IrO}_{2} / \mathrm{Ti}$ electrodes, five possible explanations could be pointed out: (1) the effects of the Nafion ${ }^{\circledR}$ ionomer, (2) the resistance between $\mathrm{IrO}_{2}$ nanoparticles and glassy carbon, $\mathrm{IrO}_{2}-\mathrm{GC}$, as well as that of among $\mathrm{IrO}_{2}$ nanoparticles contacting each other, $\mathrm{IrO}_{2}-\mathrm{IrO}_{2}$, (3) titanium ions from the oxide-Ti substrate interface, (4) the amount of the hydrated water around $\mathrm{IrO}_{2}$ crystallites, and (5) the particle size of $\mathrm{IrO}_{2}$. For the $\mathrm{CV}$ of the $\mathrm{IrO}_{2} / \mathrm{Ti}$ electrodes, no Nafion ${ }^{\circledR}$ ionomer is needed; however, Nafion ${ }^{\circledR}$ ionomer was used for the preparation of the $\mathrm{IrO}_{2}$ test electrodes in order to fix the $\mathrm{IrO}_{2}$ powder to the GC surface. It has been confirmed that the addition of the Nafion ${ }^{\circledR}$ ionomer to the $\mathrm{IrO}_{2}$ powder somewhat suppresses the catalytic activity of the catalysts for the ORR. In addition, the two possible contact resistances between $\mathrm{IrO}_{2}-\mathrm{GC}$ as well as $\mathrm{IrO}_{2}-\mathrm{IrO}_{2}$ must be evaluated in future. The potential effect of the titanium ions was described above (3. 2). The change in the CV profiles of the $\mathrm{IrO}_{2}$ electrodes in the $\mathrm{N}_{2}$-saturated solution, along with heat-treatment temperature, strongly suggests that the iridium oxide nanoparticles heat-treated at $400^{\circ} \mathrm{C}$, at least, are hydrated state particles like $\mathrm{IrO}_{2} \cdot n \mathrm{H}_{2} \mathrm{O}$. Because the $\mathrm{IrO}_{2}$ crystallites are surrounded by a water layer, the specimen must have showed lower ORR activity than the both specimens, $\mathrm{IrO}_{2} / \mathrm{Ti}$ electrodes and $\mathrm{IrO}_{2}$ powder electrodes heat-treated at temperatures higher than $450^{\circ} \mathrm{C}$. Ioroi and his co-workers [42] used iridium oxide calcined at $400^{\circ} \mathrm{C}$ in air as the support of platinum electrocatalyst for the unitized regenerative fuel cell (URFC), which is an electrochemical cell working both as fuel cell and as a water electrolyzer [43]. Yao and his co-workers also used iridium oxide as support for platinum electrocatalyst of the URFC, while Ioroi used a hydrated iridium oxide [27]. Since those iridium-supported platinum catalysts were examined as both oxygen reduction and oxygen evolution catalysts, the catalytic behavior of individual iridium oxide for the ORR has not been discussed at length in the research. The particle size of primary $\mathrm{IrO}_{2}$ crystallites of the $\mathrm{IrO}_{2} / \mathrm{Ti}$ electrode shown in Fig. 1(B)-b) was 3-8 nm in diameter and those synthesized by the Adams fusion method shown in Figs. 10(A), (B) and (C) was $3-10 \mathrm{~nm}$ in diameter. Therefore, it is not easy to attribute the difference of the onset potentials for the ORR between the $\mathrm{IrO}_{2}$ particle electrodes and the $\mathrm{IrO}_{2} / \mathrm{Ti}$ electrodes to the difference of their particle size of $\mathrm{IrO}_{2}$. Among the five possible reasons discussed above, the forth reason, i.e. the amount of the hydrated water around $\mathrm{IrO}_{2}$ crystallites, must be probable and predominant.

It must also be noted that only a slight deviation is observed above ca. $0.2 \mathrm{~V}$ (vs RHE) between the ORR current on the electrodes rotated at 2000 
rpm and on the electrodes maintained in a stationary state. That is, the comparison of the ORR current among these oxide electrodes is not meaningless, so long as we use the values in the low current density region.

Pauporté and his co-workers investigated the valency of iridium ions in the iridium oxide film prepared by sputtering using $\mathrm{X}$-ray absorption spectroscopy (XAS) at the $\mathrm{L}_{3}$ edge of iridium atoms in $1 \mathrm{M} \mathrm{H}_{2} \mathrm{SO}_{4}$, and determined the valency of iridium to be between 3 and 3.85 when the potential varied from -0.2 to $+1 \mathrm{~V}$ (vs SCE) [44]. If we apply their results to our findings, the valency of the iridium ion at $0.69 \mathrm{~V}$ (vs RHE) and the $E_{\text {ORR }}$ of the $\mathrm{IrO}_{2}$ electrode heat-treated at $400^{\circ} \mathrm{C}$ correspond to about 0.35 . The most important finding in this study is that $\mathrm{IrO}_{2}$, not metallic $\mathrm{Ir}$, behaves as an active catalyst for the ORR in $0.5 \mathrm{H}_{2} \mathrm{SO}_{4}$ at $60^{\circ} \mathrm{C}$, and the highest $E_{\mathrm{ORR}}$ was ca. $0.84 \mathrm{~V}$ (vs RHE) on the $\mathrm{IrO}_{2} / \mathrm{Ti}$ electrodes.

\section{Conclusion}

The electrocatalytic oxygen reduction reaction (ORR) of iridium oxide coating prepared on a titanium substrate using a dip-coating method $\left(\mathrm{IrO}_{2} / \mathrm{Ti}\right)$, as well as iridium oxide nanoparticles $\left(\mathrm{IrO}_{2}\right)$ prepared by the Adams fusion method, were investigated by changing the heat-treatment air temperature at the final stage of each of these methods. Although both rutile-type oxide catalysts were found to exhibit considerable activity for the ORR in $0.5 \mathrm{M} \mathrm{H}_{2} \mathrm{SO}_{4}$ at $60^{\circ} \mathrm{C}$, the former oxide electrodes showed greater activity than the latter ones. The most active catalyst was $\mathrm{IrO}_{2} / \mathrm{Ti}$ heat-treated at $400^{\circ} \mathrm{C}$, showing ca. $0.84 \mathrm{~V}$ (vs RHE) of the onset potential for the ORR, $E_{\mathrm{ORR}}$, so long as evaluated by cyclic voltammetry. However, both the activity and the $E_{\mathrm{ORR}}$ seem to be almost the same among the $\mathrm{IrO}_{2} / \mathrm{Ti}$ electrodes heat-treated at different temperatures between $400^{\circ} \mathrm{C}$ and $550^{\circ} \mathrm{C}$, given the currents for the $\mathrm{ORR}$ on $\mathrm{IrO}_{2} / \mathrm{Ti}$ electrodes were evaluated with their surface areas. It must be noted that $\mathrm{IrO}_{2}$, but neither metallic Ir nor hydrated $\mathrm{IrO}_{2}$, behave as an active catalyst for the ORR in an acidic solution.

We have previously demonstrated that the catalytic activity of an $\mathrm{IrO}_{2} / \mathrm{Ti}$ electrode for the ORR can be greatly enhanced by the formation of a solid solution with another element, vanadium for example, as well as with the increase in surface area [31]. The onset potential for the ORR of the $\operatorname{Ir}_{0.6} \mathrm{~V}_{0.4} \mathrm{O}_{2} / \mathrm{Ti}$ electrode was higher than that of a Pt plate electrode, although the current density was expressed with the current per geometric surface area.

The result that we feel is of utmost importance is that the catalytic performance of rutyle-type oxide of $\mathrm{IrO}_{2}$ on the ORR may provide useful insight into how to design the oxide cathode catalyst. This investigation using iridium oxide as the cathode is the first-step towards the development 
of less expensive and anti-corrosive oxide cathodes in the future.

\section{Acknowledgments}

This work was supported in part by the "Polymer Electrolyte Fuel Cell Program; Development of Next Generation Technology" from the New Energy and Industrial Technology Development Organization (NEDO) of Japan.

\section{References}

[1] B.C. Beard, P.N. Ross, J. Electrochem. Soc. 137 (1990) 3368.

[2] T. Toda, H. Igarashi, H. Uchida, M. Watanabe, J. Electrochem. Soc. 146 (1999) 3750.

[3] U. A. Paulus, T. J. Schmidt, H. A. Gasteiger, R. J. Behm, J. Electrochem. Soc. 495 (2001) 134 .

[4] H. Yang, W. Vogel, C. Lamy, N. Alonso-Vante, J. Phys. Chem. B 108, (2004) 11024.

[5] P. Yu, M. Pemberton, P. Plasse, J. Power Sources 144 (2005) 11.

[6] B. Wang, J. Power Sources 152 (2005) 15.

[7] J-H. Kim, A. Ishihara, S. Mitsushima, N. Kamiya, K-I. Ota, Electrochim. Acta 52 (2007) 2492.

[8] J. Prakash, D. A. Tryk, W. Aldred, E. B. Yeager, J. Appl. Electrochem. 29 (1999) 1463.

[9] F. Mazza, S. Trassatti, J. Electrochem. Soc. 110 (1963) 847.

[10] K. Lee, A. Ishihara, S. Mitsushima, N. Kamiya, K-I. Ota, Electrochim. Acta 49 (2004) 3479.

[11] E. Claud, T. Addou, J.-M. Latour, P. Aldebert, J. Appl. Electrochem. 28 (1998) 57.

[12] J. P. Collman, P. S. Wagenknecht, J. E. Hutchison, Angew. Chem. Int. Ed. Engl. 33 (1994) 1537.

[13] D. Susac, A. Sode, L. Zhu, P.C. Wong, M. Teo, D. Bizzotto, K.A.R. 
Mitchell, R.R. Parsons, S.A. Campbell, J. Phys. Chem. B 110 (2006) 10762.

[14] K. Lee, L. Zhang, J. Zhang, Electrochem. Commun. 9 (2007) 1704.

[15] N. A. Vante, H. Tributsch, Nature 323 (1986),431.

[16] O. Savadogo, K. Lee, K. Oishi, S. Mitsushima, N. Kamiya, K-I. Ota, Electrochem. Commun. 6 (2004) 105.

[17] A. Ishihara, K. Lee, S. Doi, S. Mitsushima, N. Kamiya, M. Hara, K. Domen, K. Fukuda, K-I. Ota, Electrochem. Solid-State Lett. 8 (2005) A201.

[18] Y. Liu, A. Ishihara, S. Mitsushima, N. Kamiya, K-I. Ota, Electrochem. Solid-State Lett. 8 (2005) A400.

[19] J. Rolewicz, Ch. Comminellis, E. Plattner, J. Hinden, Chimia 42 (1988) 75.

[20] J. Rolewicz, Ch. Comminellis, E. Plattner, J. Hinden, Electrochim. Acta 33 (1988) 573.

[21] K. Kameyama, K. Tsukada, K. Yahikozawa, Y. Takasu, J. Electrochem. Soc. 141 (1994) 643.

[22] D. S. Gnanamuthu, J. V. Petrocelli, J. Electrochem. Soc. 114 (1967) 1036.

[23] A. J. Appleby, J. Electroanal. Chem. 27 (1970) 325.

[24] K. Lee, L. Zhang, J. Zhang, J. Power Sources 165 (2007) 108.

[25] K. Lee, L. Zhang, J. Zhang, J. Power Sources 170 (2007) 291.

[26] T. Ioroi, K. Kitazawa, K. Yasuda, Y. Yamamoto, H. Takenaka, J. Electrochem. Soc. 147 (2000) 2018.

[27] W. Yao, J. Yang, J. Wang, Y. Nuli, Electrochem. Commun. 9 (2007) 1029.

[28] C.-C. Chang, T.-C. Wen, J. Electrochem. Soc. 143 (1996) 1485. 
[29] C.-C. Chang, T.-C. Wen, Mater. Chem. Phys. 47 (1997) 203.

[30] Y. Takasu, W. Sugimoto, M. Yoshitake, Electrochemistry 75 (2007) 105.

[31] Y. Takasu, N. Yoshinaga, W. Sugimoto, Electrochem. Commun. 10 (2008) 668.

[32] Y. Murakami, T. Kondo, Y. Shimoda, H. Kaji, K. Yahikozawa, Y. Takasu, J. Alloys and Compounds 239 (1996) 111.

[33] Y. Murakami, T. Nakamura, X.-G. Zhang, Y. Takasu, J. Alloys and Compounds 259 (1997) 196.

[34] R. Adams, R. Shriner, J. Am. Chem. Soc. 45 (1923) 2171.

[35] T. J. Schmidt, U. A. Paulus, H. A. Gasteiger, R. J. Behm, J. Electroanal. Chem. 508 (2001) 41.

[36] U. A. Paulus, T. J. Schmidt, H. A. Gasteiger, R. J. Behm, J. Electroanal. Chem. 495 (2001) 134.

[37] B. E. Conway, J. Electrochem. Soc. 138 (1991) 1539.

[38] S. Trasatti, P. Kurzweil, Platinum Metal Rev. 38 (1994) 46.

[39] T. Arikawa, Y. Takasu, Y. Murakami, K. Asakura, Y. Iwasawa, J. Phys. Chem. B 102 (1998) 3736.

[40] K. Tsukada, K. Kameyama, K. Yahikozawa, Y. Takasu, Denki Kagaku (presently Electrochemistry) 61 (1993) 435.

[41] L. D. Burke, E. J. M. O’Sullican, J. Electroanal. Chem. 117 (1989) 155.

[42] P. Siviglia, A. Daghetti, S. Trasatti, Colloids and Surfaces, 7 (1983) 15.

[43] S. Lavine, A. L. Smith, Discuss. Faraday Soc. 128 (1981) 2141.

[44] T. Ioroi, K. Kitazawa, K. Yasuda, Y. Yamamoto, H. Takenaka, J. Appl. Electrochem. 31 (2001) 1179. 
[45] F. Mitlitsky, B. Myers, A. Weisberg, Energy \& Fuels 12 (1998) 56.

[46] T. Pauporté, D. Aberdam, J.-L. Hazemann, R. Faure, R. Durand, J. Electroanal. Chem. 465 (1999) 88.

\section{Fugure captions}

Fig. 1(A) A typical SEM image of an $\mathrm{IrO}_{2} / \mathrm{Ti}$ electrode prepared by the dip-coating method at $450^{\circ} \mathrm{C}$. Higher magnificatuion SEM images the crystallites part, a), and the flat part, b), are shown in Fig. 1(B).

Fig. 1(B) High magnification SEM images of the crystallites part a) and the flat part b) shown in Fig. 1(A).

Fig. 2 XRD patterns of $\mathrm{IrO}_{2} / \mathrm{Ti}$ electrodes prepared at various temperatures by the dip-coating method.

Preparation temperatures: a) $400^{\circ} \mathrm{C}$, b) $450^{\circ} \mathrm{C}$, c) $500^{\circ} \mathrm{C}$, d) $550^{\circ} \mathrm{C}$.

Fig. 3 Cyclic voltammograms of $\mathrm{IrO}_{2} / \mathrm{Ti}$ electrodes prepared at various temperatures.

Preparation temperatures: A) $400^{\circ} \mathrm{C}$, B) $450^{\circ} \mathrm{C}$, C) $500^{\circ} \mathrm{C}$, D) $550^{\circ} \mathrm{C}$. Electrolytes: broken lines [a]; in $\mathrm{N}_{2}$-saturated $0.5 \mathrm{M} \mathrm{H}_{2} \mathrm{SO}_{4}, 60^{\circ} \mathrm{C}$, solid lines [b]; in $\mathrm{O}_{2}$-saturated $0.5 \mathrm{M} \mathrm{H}_{2} \mathrm{SO}_{4}, 60^{\circ} \mathrm{C}$. Electrode potential sweep rate: $5 \mathrm{mV} \mathrm{s}^{-1}$.

Fig. 4 ORR-current curves of $\mathrm{IrO}_{2} / \mathrm{Ti}$ electrodes prepared at various temperatures.

Preparation temperatures: a) $400^{\circ} \mathrm{C}$, b) $450^{\circ} \mathrm{C}$, c) $500^{\circ} \mathrm{C}$, d) $550^{\circ} \mathrm{C}$. Electrolyte: $0.5 \mathrm{M} \mathrm{H}_{2} \mathrm{SO}_{4}, 60^{\circ} \mathrm{C}$. Electrode potential sweep rate: $5 \mathrm{mV} \mathrm{s}^{-1}$.

Fig. 5 ORR-current curves presented by current density determined by the estimated surface area, ESA, which was evaluated with the pseudocapacitance of each $\mathrm{IrO}_{2} / \mathrm{Ti}$ electrode prepared at various temperatures.

Preparation temperatures: a) $400^{\circ} \mathrm{C}$, b) $450^{\circ} \mathrm{C}$, c) $500^{\circ} \mathrm{C}$, d) $550^{\circ} \mathrm{C}$.

Electrolyte: $0.5 \mathrm{M} \mathrm{H}_{2} \mathrm{SO}_{4}, 60^{\circ} \mathrm{C}$. Electrode potential sweep rate: $5 \mathrm{mV} \mathrm{s}^{-1}$. The estimated surface area, ESA, of these electrodes was evaluated using the cyclic voltammograms measured on the $\mathrm{N}_{2}$-saturated electrolytes shown in Fig. 3, assuming that of the monolayer capacitance of the $\mathrm{IrO}_{2}$ was $80 \mu \mathrm{F} \mathrm{cm}^{-2}$. 
Fig. 6 A typical SEM image of a $\mathrm{La}_{2} \mathrm{O}_{3}$-treated $\mathrm{IrO}_{2} / \mathrm{Ti}$ electrode.

Fig. 7 Steady state cyclic voltammograms of a $\mathrm{La}_{2} \mathrm{O}_{3}$-treated $\mathrm{IrO}_{2} / \mathrm{Ti}$ electrode and of the $\mathrm{IrO}_{2} / \mathrm{Ti}$ electrode prepared at $450^{\circ} \mathrm{C}$ presented in Fig. 3-b).

Electrodes: a) $\mathrm{La}_{2} \mathrm{O}_{3}$-treated $\mathrm{IrO}_{2} / \mathrm{Ti}$ electrode, b) $\mathrm{IrO}_{2} / \mathrm{Ti}$ electrode prepared at $450^{\circ} \mathrm{C}$ presented in Fig. 3-b).

Fig. 8 ORR-current curves of the $\mathrm{La}_{2} \mathrm{O}_{3}$-treated $\mathrm{IrO}_{2} / \mathrm{Ti}$ electrode, the $\mathrm{IrO}_{2} / \mathrm{Ti}$ electrode and the porous $\mathrm{Ir}_{0.6} \mathrm{~V}_{0.4} \mathrm{O}_{2} / \mathrm{Ti}$ electrode.

Electrodes: a) $\mathrm{IrO}_{2} / \mathrm{Ti}$ electrode, b) $\mathrm{La}_{2} \mathrm{O}_{3}$-treated $\mathrm{IrO}_{2} / \mathrm{Ti}$ electrode, d) porous $\operatorname{Ir}_{0.6} \mathrm{~V}_{0.4} \mathrm{O}_{2} / \mathrm{Ti}$ electrode [31]. The preparation temperature of these oxide electrodes were $450^{\circ} \mathrm{C}$. c) a platinum plate electrode.

Fig. 9 XRD patterns of $\mathrm{IrO}_{2}$ nanoparticles prepared by the Adams fusion method.

Heat-treatment temperatures: a) $400^{\circ} \mathrm{C}$, b) $450^{\circ} \mathrm{C}$, c) $500^{\circ} \mathrm{C}$.

Fig.10-(A) TEM images with different magnifications of $\mathrm{IrO}_{2}$ nanoparticles heat-treated at $400^{\circ} \mathrm{C}$. a): low magnification, b): high magnification

Fig.10-(B) TEM images with different magnifications of $\mathrm{IrO}_{2}$ nanoparticles heat-treated at $450^{\circ} \mathrm{C}$. a): low magnification, b): high magnification

Fig.10-(C) TEM images with different magnifications of $\mathrm{IrO}_{2}$ nanoparticles heat-treated at $500^{\circ} \mathrm{C}$. a): low magnification, b): high magnification

Fig.11-(A) Cyclic voltammograms of $\mathrm{IrO}_{2}$ nanoparticles heat-treated at $400^{\circ} \mathrm{C}$.

Electrolytes: broken line [a)]: $\mathrm{N}_{2}$-saturated $0.5 \mathrm{M} \mathrm{H}_{2} \mathrm{SO}_{4}, 60^{\circ} \mathrm{C}$; solid line [b)] and long- and short-dashed short lines [c)]: $\mathrm{O}_{2}$-saturated $0.5 \mathrm{M} \mathrm{H}_{2} \mathrm{SO}_{4}$, $60^{\circ} \mathrm{C}$. For the solid line [b)]: the electrode was not rotated. For the longand short-dashed line [c)]: the electrode was rotated at $2000 \mathrm{rpm}$. Electrode potential sweep rate: $5 \mathrm{mV} \mathrm{s}^{-1}$.

Fig.11-(B) Cyclic voltammograms of $\mathrm{IrO}_{2}$ nanoparticles heat-treated at $450^{\circ} \mathrm{C}$. The electrolyte, measurement conditions and nomination of the voltammograms are same as the caption of Fig.5-(A).

Fig.11-(C) Cyclic voltammograms of $\mathrm{IrO}_{2}$ nanoparticles heat-treated at $500^{\circ} \mathrm{C}$. 
The electrolyte, measurement conditions and nomination of the voltammograms are same as the caption of Fig.5-(A). 


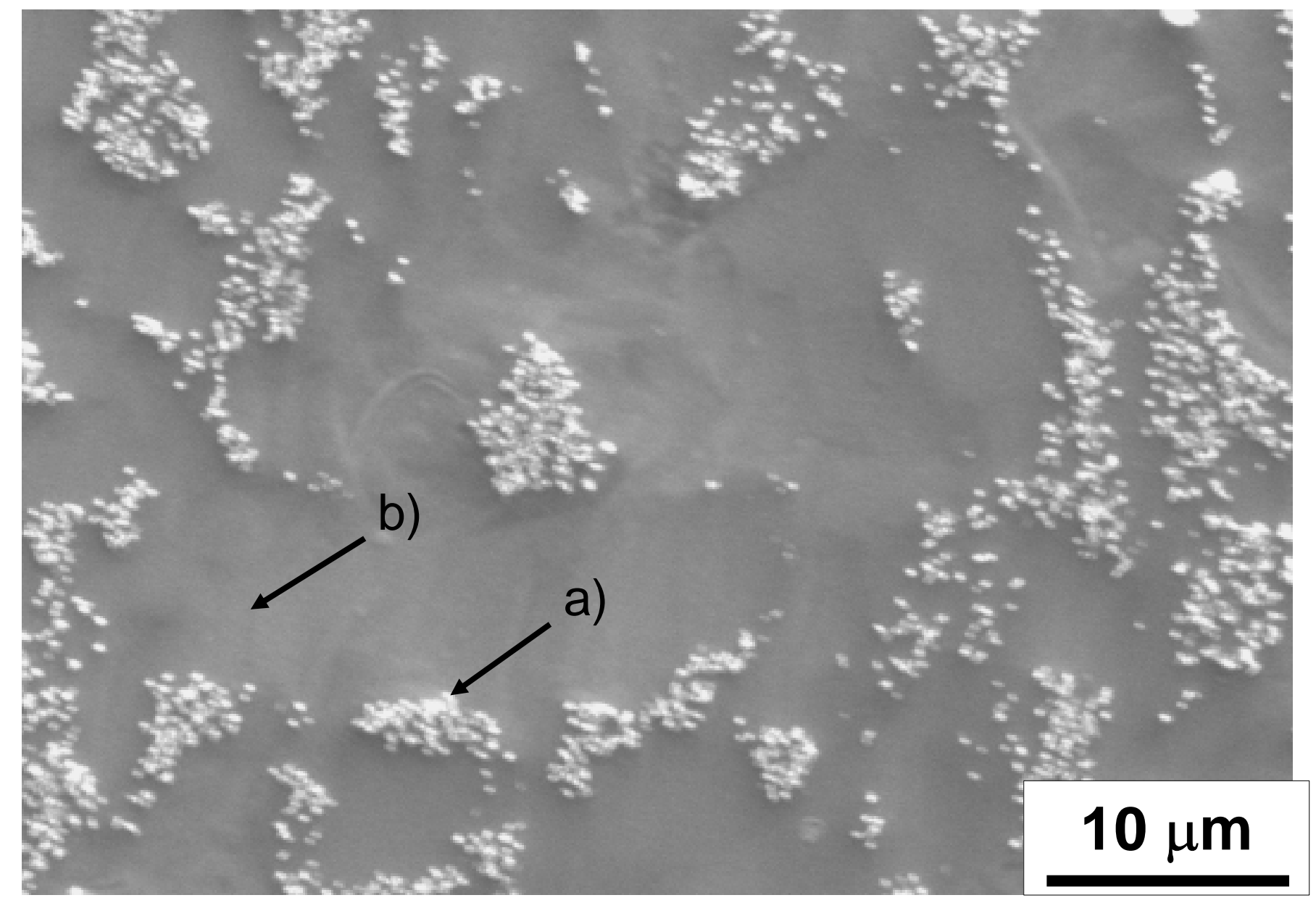

Fig. 1 (A) Yoshinaga et al. 


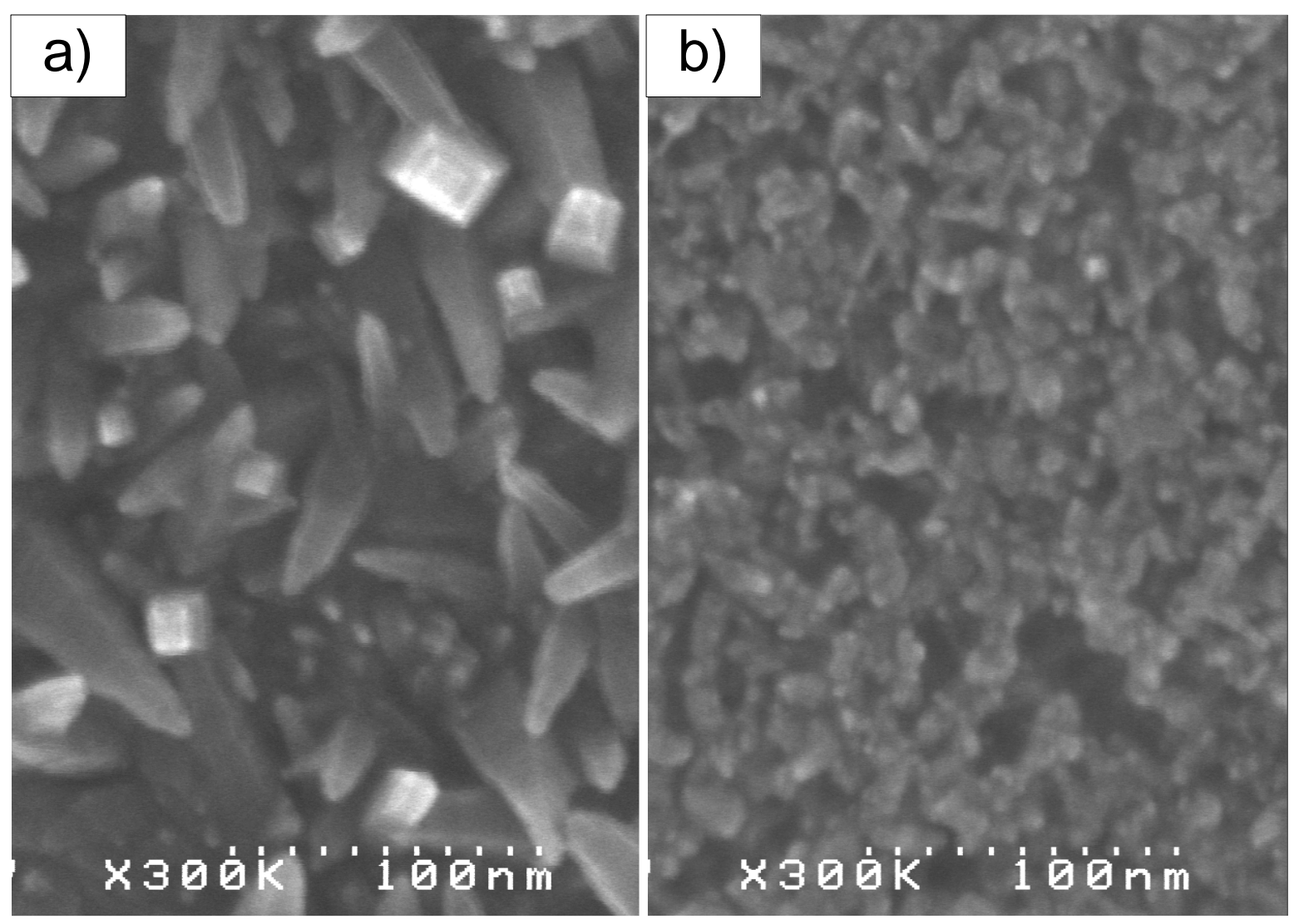

Fig. 1 (B) Yoshinaga et al. 


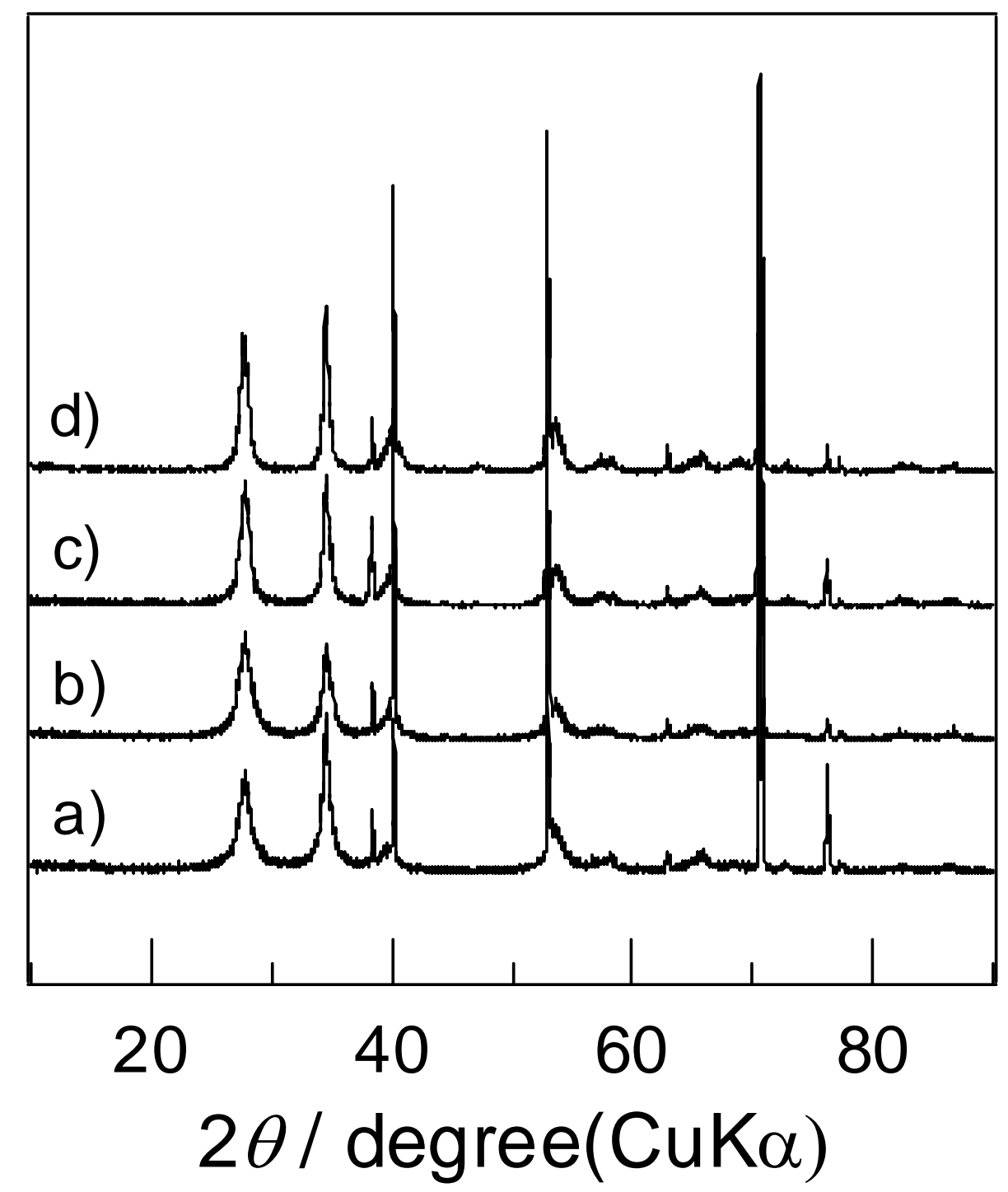

Fig. 2 Yoshinaga et al. 

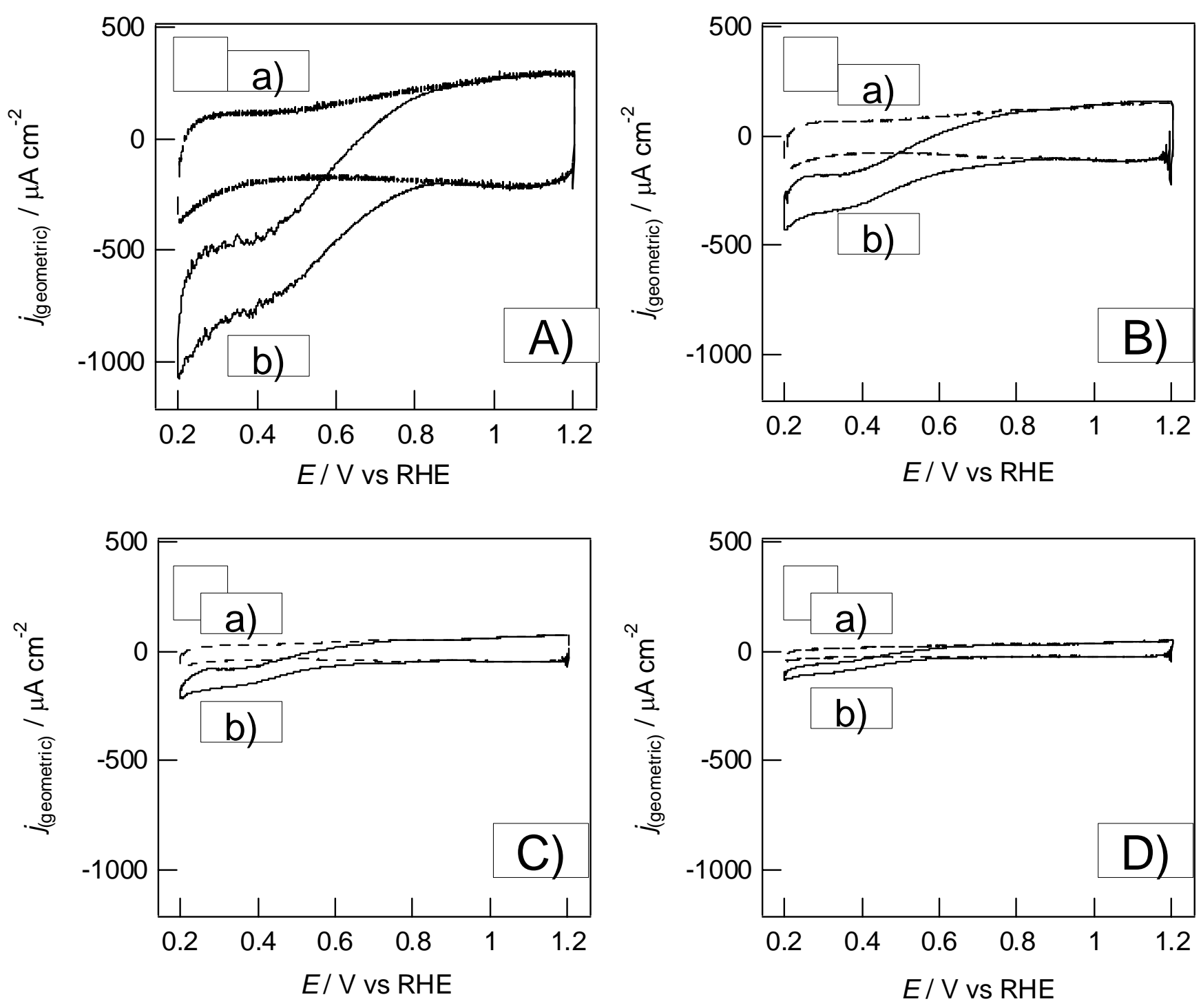

Fig. 3 Yoshinaga et al. 


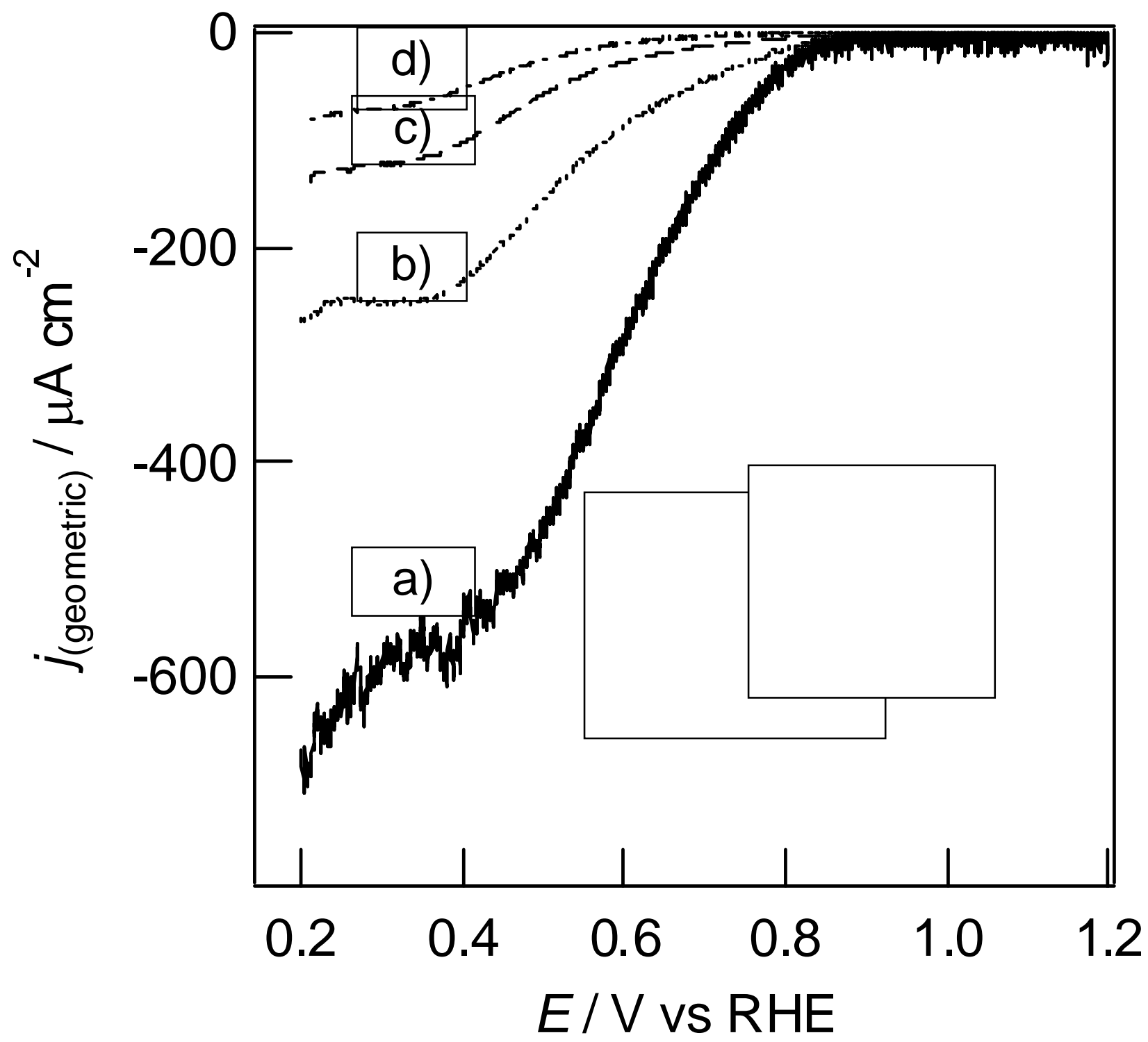

Fig. 4 Yoshinaga et al. 


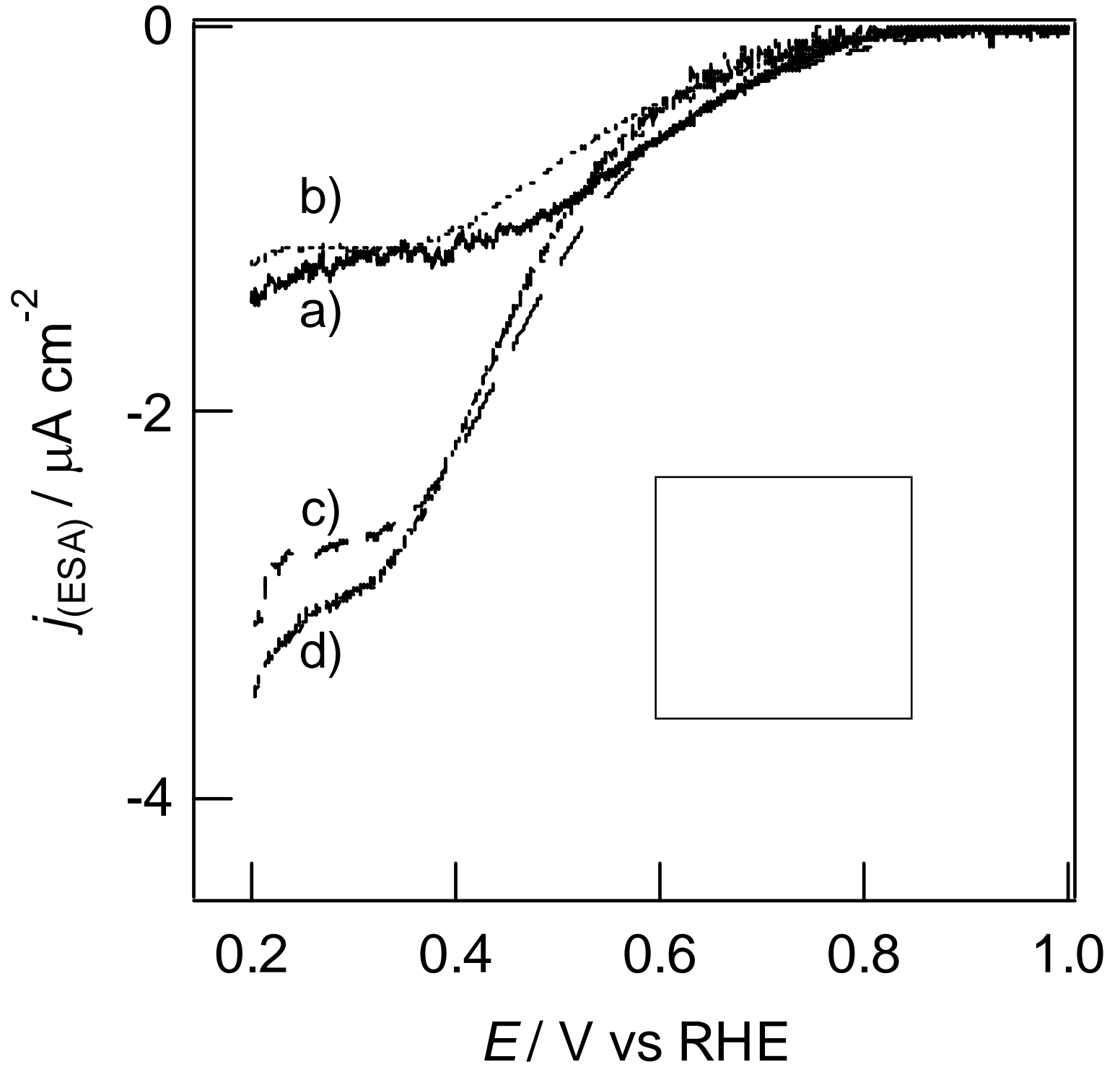

Fig. 5 Yoshinaga et al. 


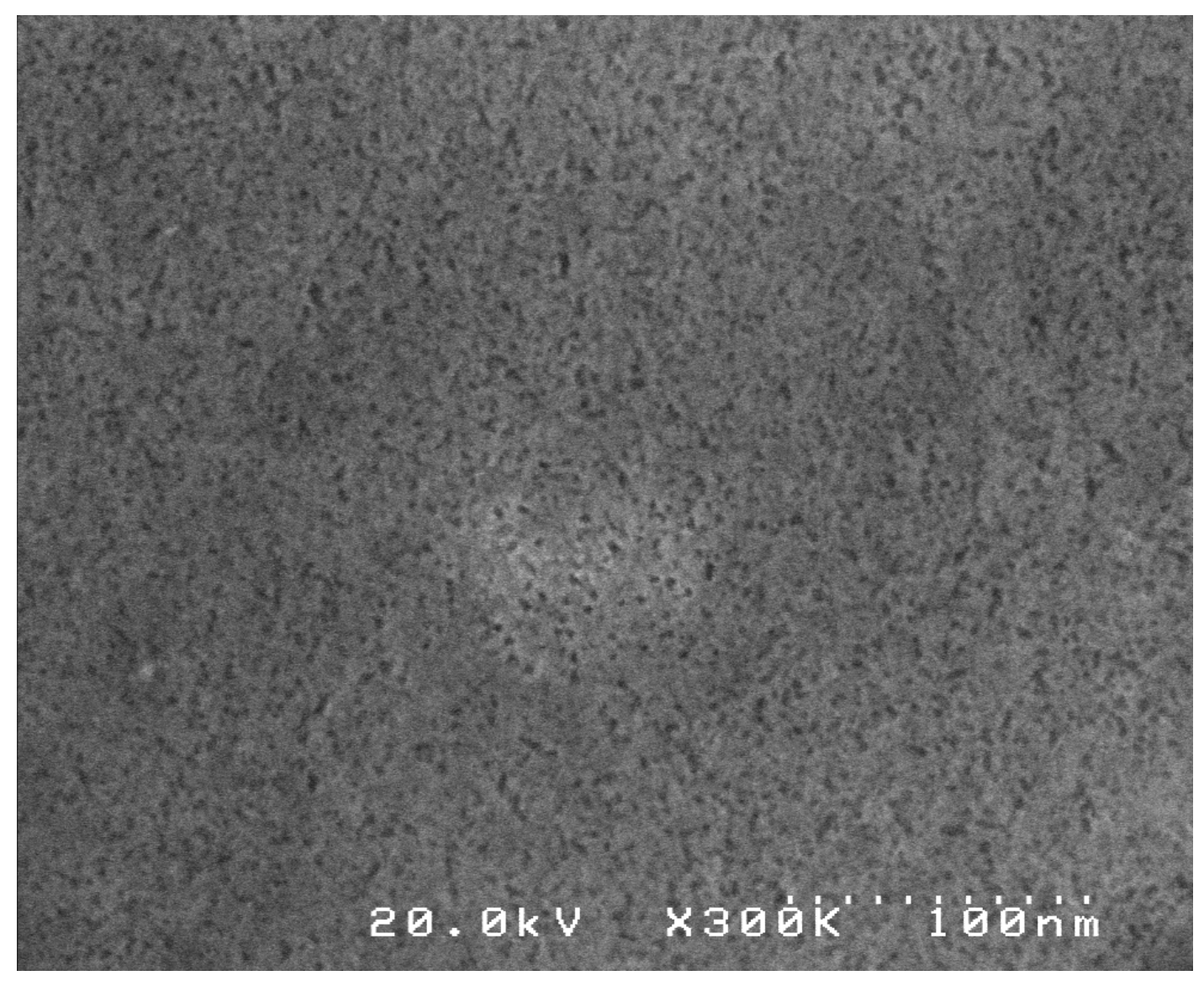

Fig. 6 Yoshinaga et al. 


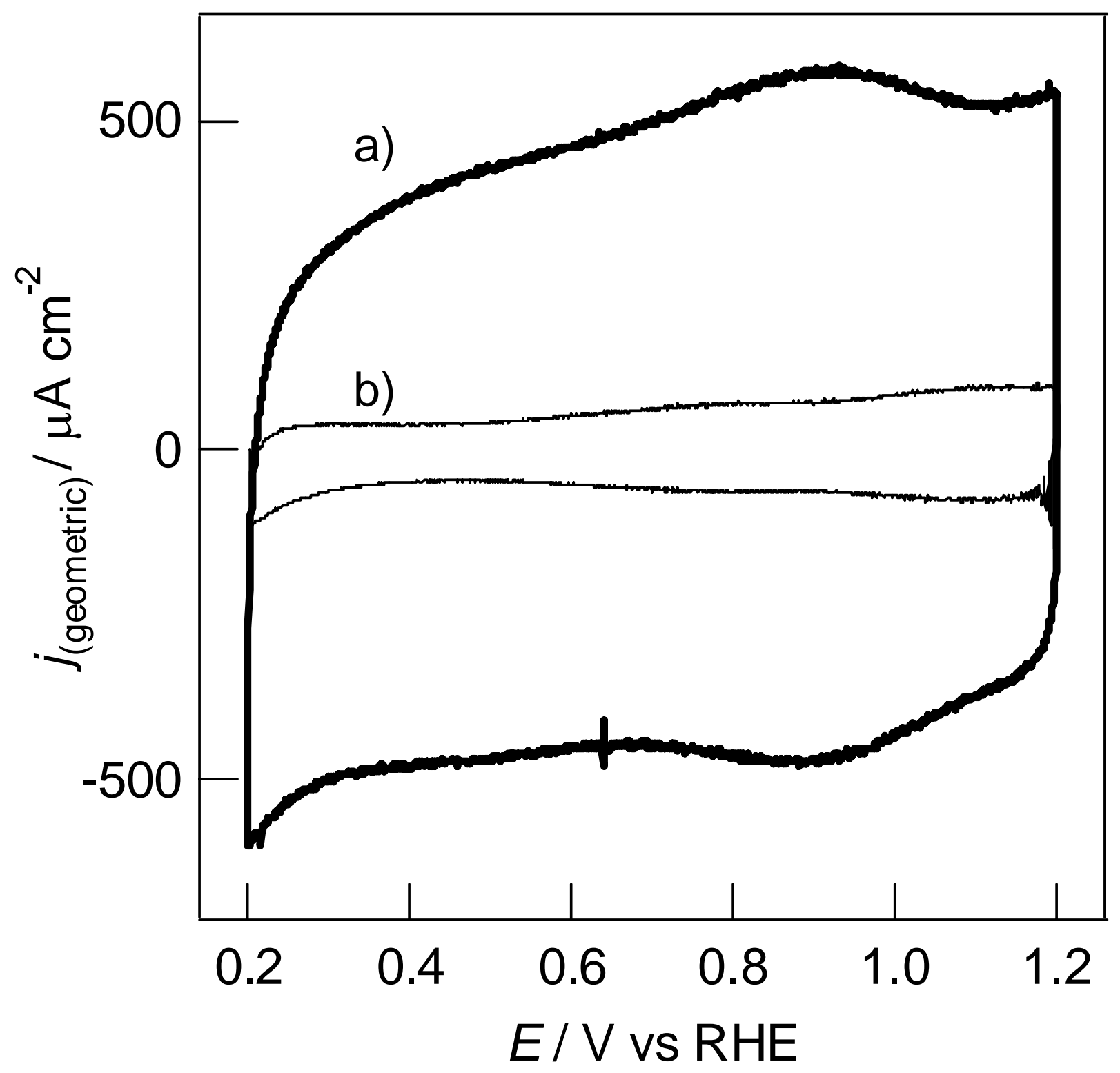

Fig. 7 Yoshinaga et al. 


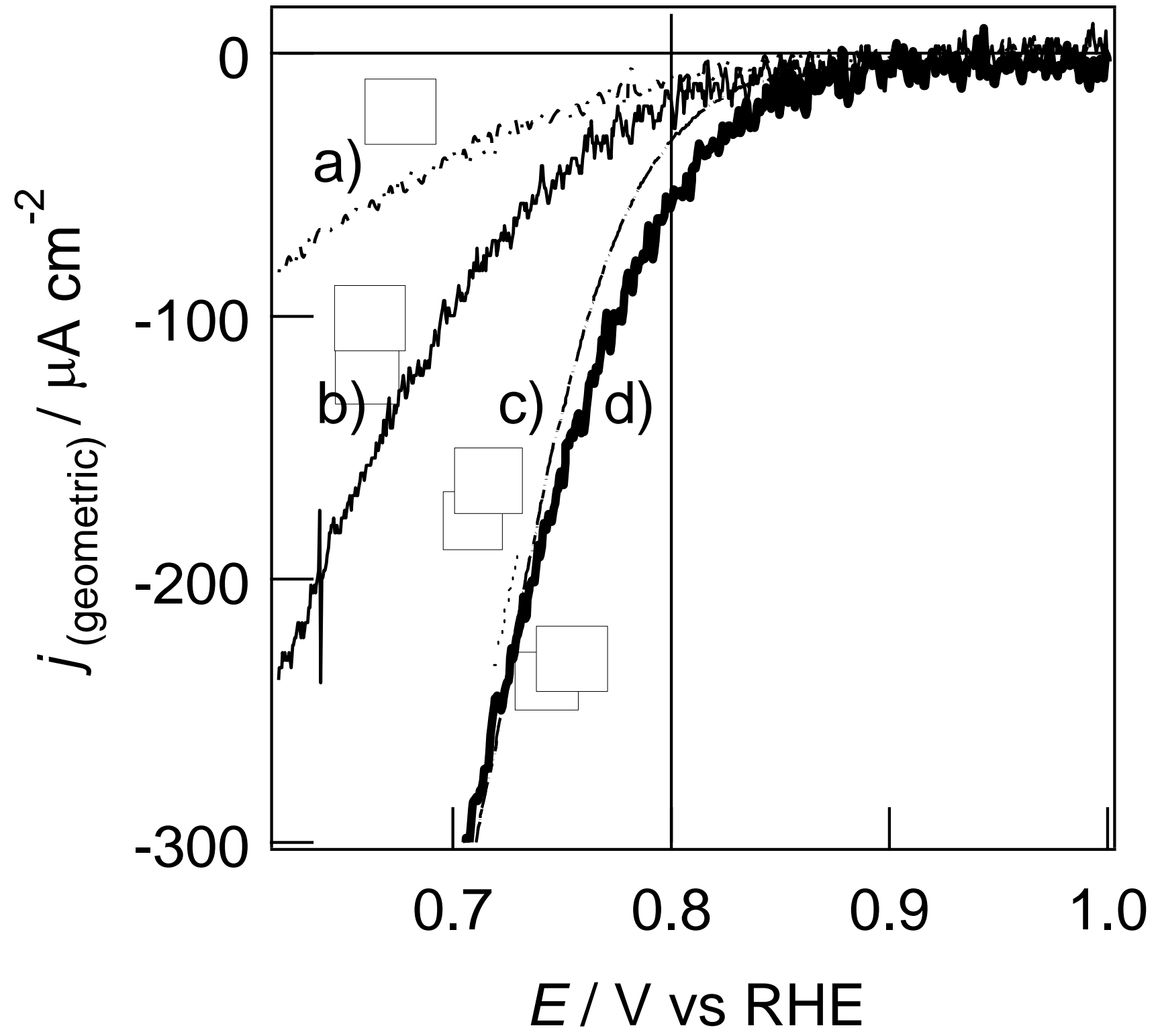

Fig. 8 Yoshinaga et al. 


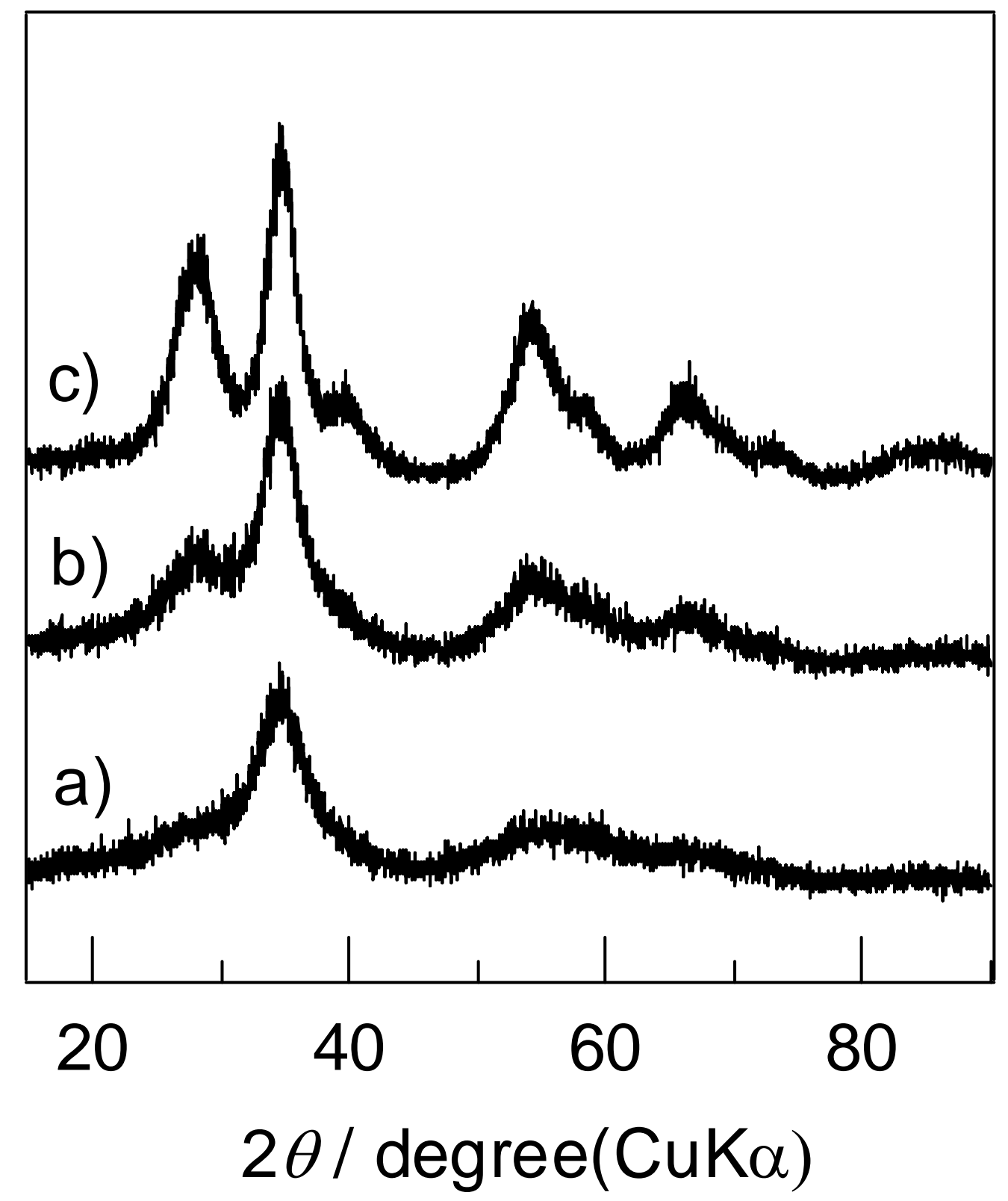

Fig. 9 Yoshinaga et al. 


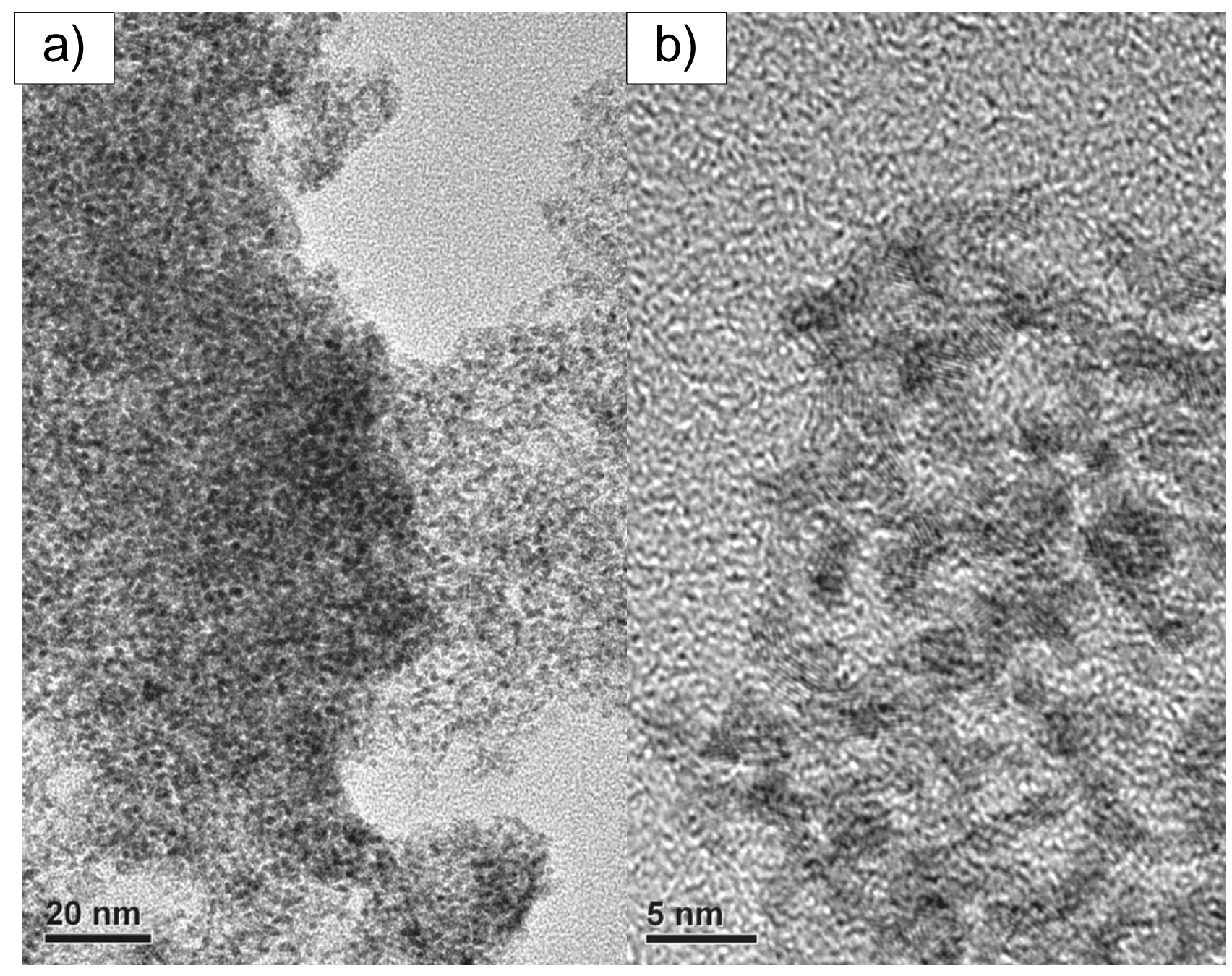

Fig. 10(A) Yoshinaga et al. 


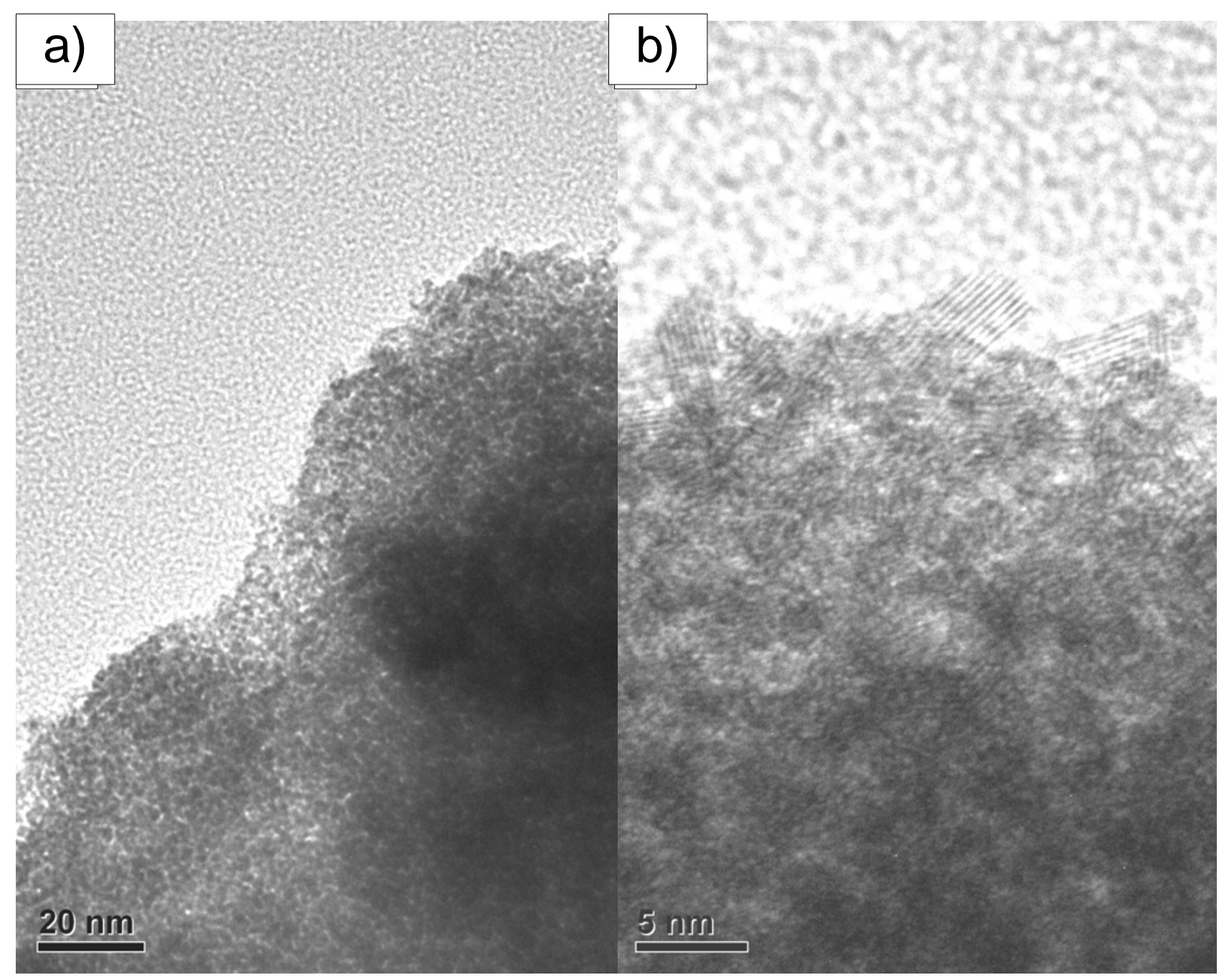

Fig. 10(B) Yoshinaga et al. 


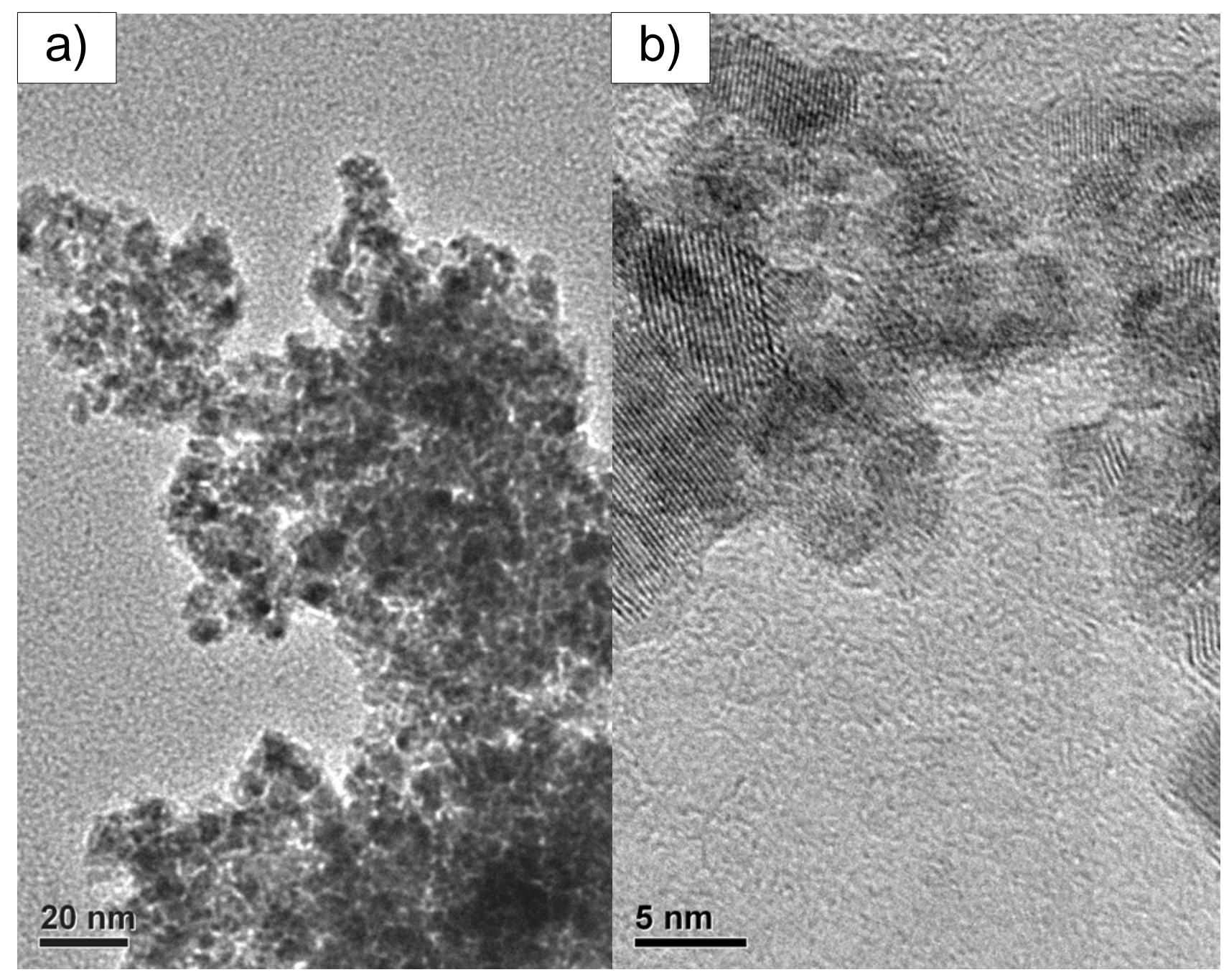

Fig. 10(C) Yoshinaga et al. 


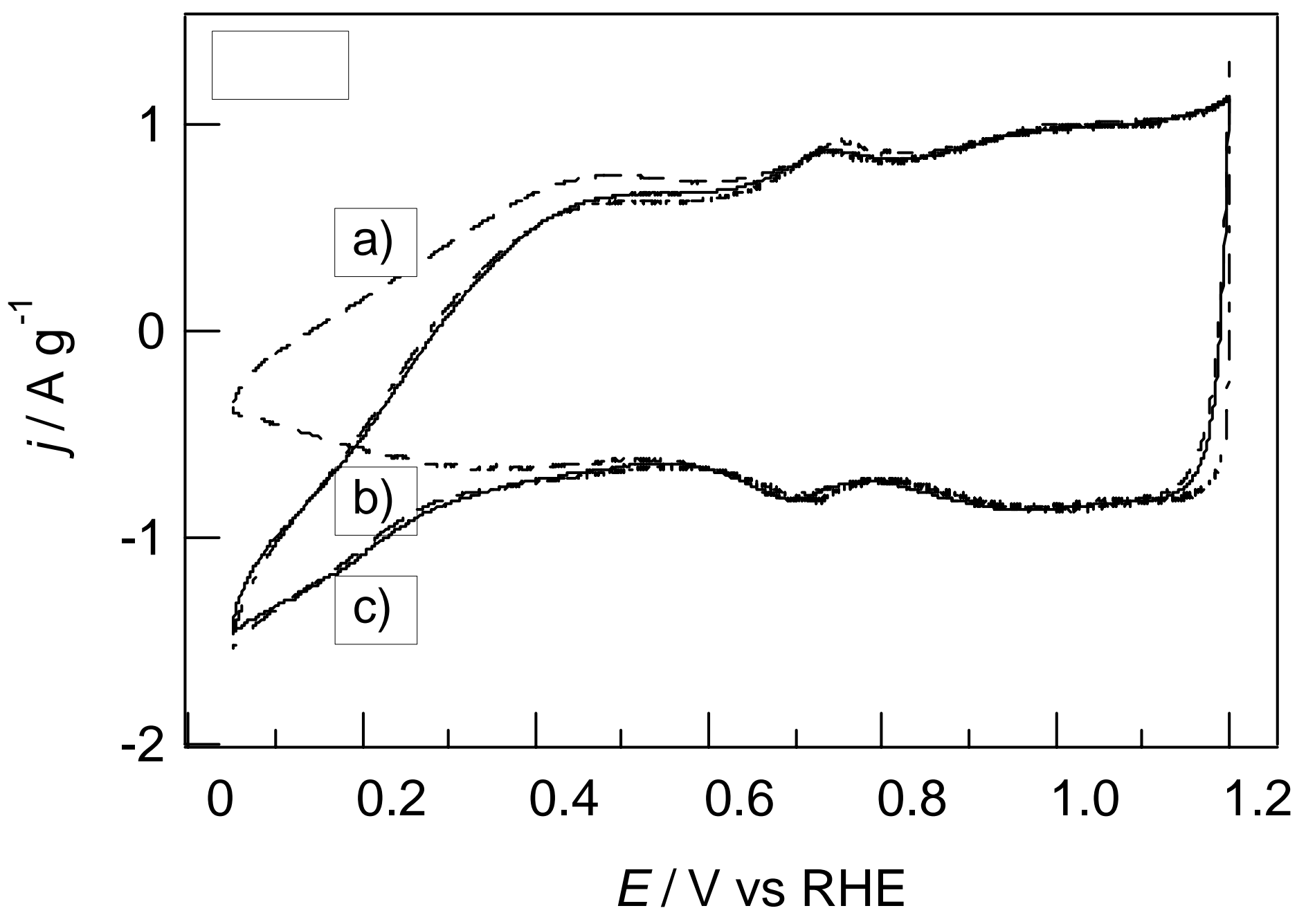

Fig. 11(A) Yoshinaga et al. 


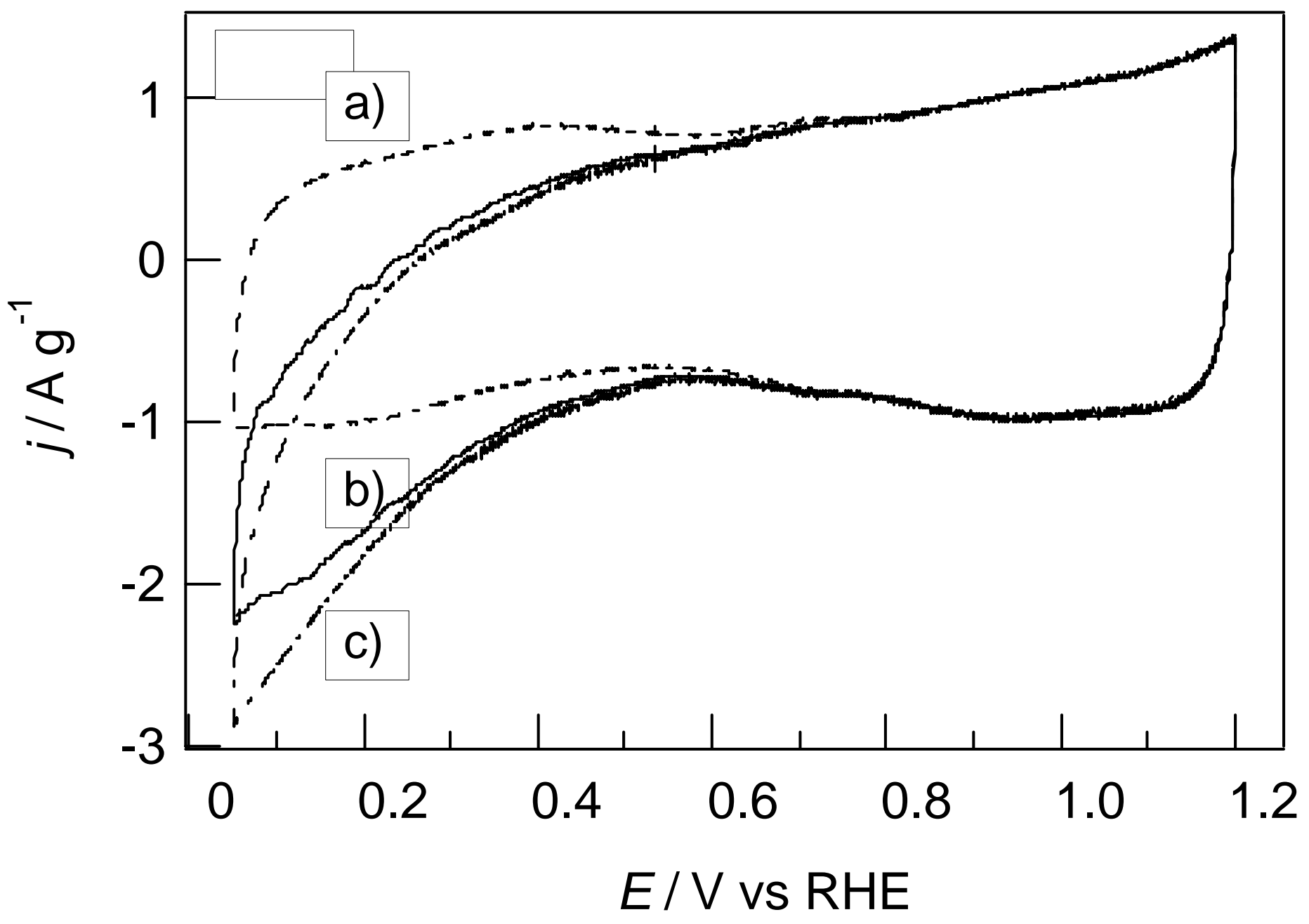

Fig. 11(B) Yoshinaga et al. 


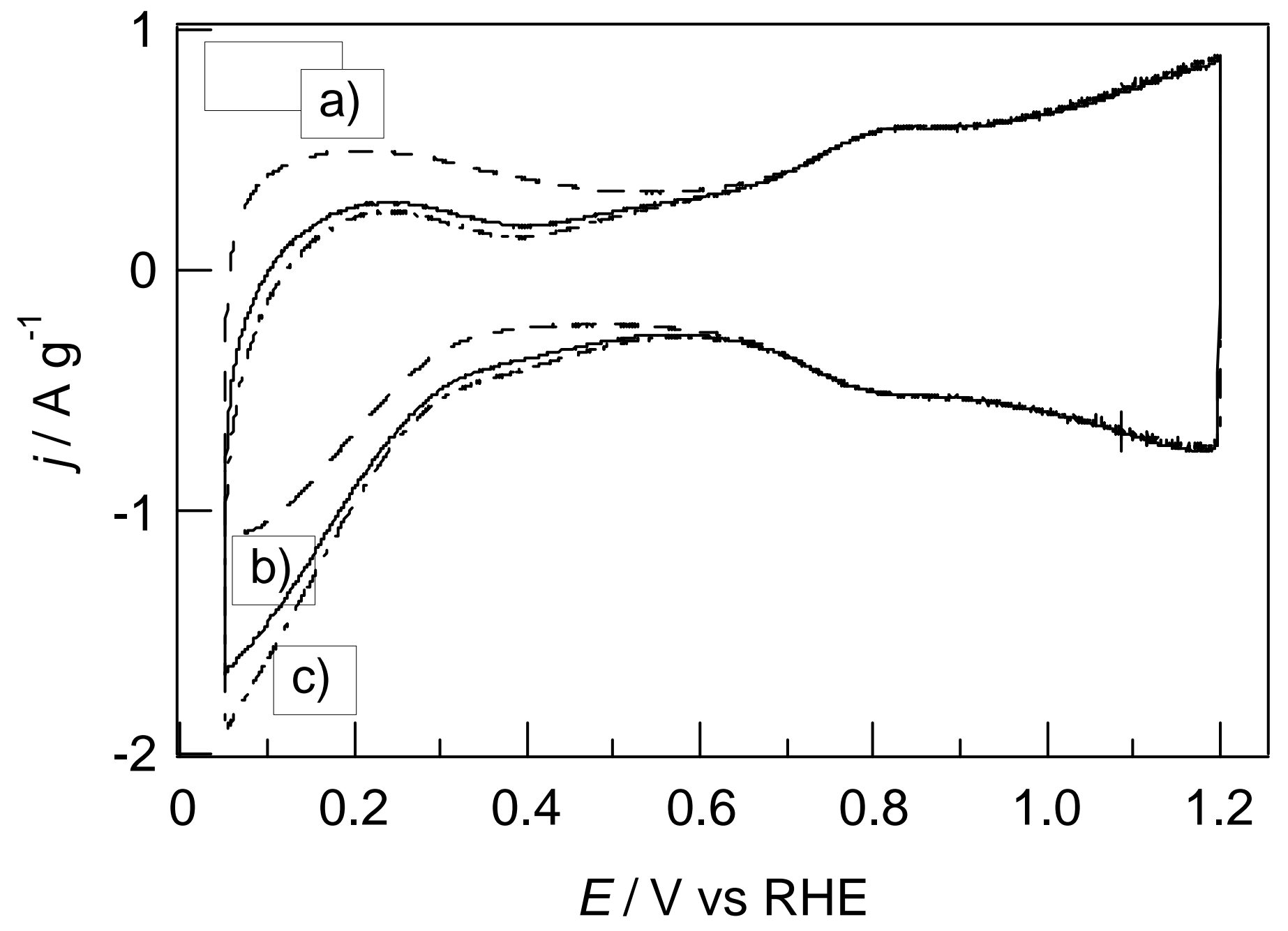

Fig. 11(C) Yoshinaga et al. 